\title{
Leptin secretion and negative autocrine crosstalk with insulin in brown adipocytes
}

\author{
D Kraus, M Fasshauer ${ }^{1}$, V Ott, B Meier, M Jost, H H Klein \\ and J Klein \\ Department of Internal Medicine I, Medical University of Lübeck, Ratzeburger Allee 160, 23538 Lübeck, Germany \\ ${ }^{1}$ Department of Internal Medicine III, University of Leipzig, 04103 Leipzig, Germany \\ (Requests for offprints should be addressed to J Klein; Email: johannes.klein@medinf.mu-luebeck.de)
}

\begin{abstract}
Leptin is an important adipocytokine whose main regulative effects on energy metabolism are exerted via activation of signalling pathways in the central nervous system. Another important regulator of energy homeostasis is insulin. The role of direct autocrine leptin effects on adipose tissue and crosstalk with insulin, in particular in the thermogenically active brown adipose tissue, remains unclear. In the present study, we have investigated leptin secretion and interaction with insulin in highly insulinresponsive immortalised mouse brown adipocytes. Leptin was secreted in a differentiation-dependent manner, and acute leptin treatment of mature adipocytes dose- and time-dependently stimulated phosphorylation of STAT3 and MAP kinase. Interestingly, acute pretreatment of fully differentiated brown adipocytes with leptin (100 nM) significantly diminished insulin-induced glucose uptake
\end{abstract}

by approximately $25 \%$. This inhibitory effect was timedependent and maximal after $60 \mathrm{~min}$ of leptin prestimulation. Furthermore, it correlated with a 35\% reduction in insulin-stimulated insulin receptor kinase activity after acute leptin pretreatment. Insulin-induced insulin receptor substrate-1 tyrosine phosphorylation and binding to the regulatory subunit p85 of phosphatidylinositol 3-kinase (PI 3-kinase) were diminished by approximately $60 \%$ and $40 \%$, respectively. Taken together, this study has demonstrated strong differentiation-dependent leptin secretion in brown adipocytes and PI 3-kinase-mediated negative autocrine effects of this hormone on insulin action. Direct peripheral leptin-insulin crosstalk may play an important role in the regulation of energy homeostasis. Journal of Endocrinology (2002) 175, 185-191

\section{Introduction}

Adipose tissue has emerged as an endocrine organ that is central to the regulation of energy homeostasis (Ahima \& Flier 2000, Shuldiner et al. 2001). The adipocyte-derived hormone leptin appears to be an important player in this regard (Friedman et al. 1998, Spiegelman \& Flier 2001). Hypothalamic leptin stimulation regulates the expression of a number of orexigenic and anorexigenic neuropeptides which, in turn, results in decreased food intake and increased energy expenditure mediated via activation of the sympathetic nervous system (Spiegelman \& Flier 2001).

The densely innervated brown adipose tissue is an effector tissue of the sympathetic nervous system. It contributes to the regulation of energy homeostasis by virtue of expression of the mitochondrial uncoupling protein 1, which uncouples mitochondrial respiration, thereby providing heat instead of generating ATP (Nicholls \& Locke 1984, Klaus 1997, Lowell \& Flier 1997). Similar to white adipose tissue, brown adipose tissue is highly insulin sensitive. Furthermore, we have recently shown that immortalised brown adipocytes provide an excellent model to investigate insulin signalling and potential insulin resistance-inducing mechanisms (Fasshauer et al. 2000, 2001, Klein et al. 1999, 2000, 2002). Immortalised brown adipocytes differentiated in culture resemble mature primary adipocytes with respect to morphological, molecular and functional characteristics including adrenergic and insulin sensitivity (Klein et al. 1999, 2002).

Impaired insulin action in white and brown adipose tissue has been shown to be associated with the development of diabetes and features of the insulin-resistance syndrome (Kahn \& Flier 2000, Abel et al. 2001, Guerra et al. 2001). Expression of the long form of the leptin receptor has been demonstrated for both white and brown adipose tissue (Siegrist-Kaiser et al. 1997), but only a few and controversial reports exist about direct leptin effects on insulin action. In vivo and in vitro studies in human and rat white adipose tissue found either negative effects (Muller et al. 1997, Zhang et al. 1999) or no leptin influence 
at all (Mick et al. 1998, Zierath et al. 1998). For the thermogenically active brown adipose tissue, direct crosstalk of leptin with insulin signalling and action is completely unknown.

Here, we show a robust differentiation-associated increase in leptin secretion in brown adipocytes. Furthermore, we demonstrate autocrine negative crosstalk on the proximal level of insulin signalling which transiently induces insulin resistance and suggests a pathophysiologically important direct interaction between these two signalling systems.

\section{Materials and Methods}

\section{Materials}

Recombinant mouse leptin was purchased from Calbiochem, Inc. (San Diego, CA, USA), anti-insulin receptor substrate (IRS)-1 and anti-p85 antibodies, as well as recombinant IRS-1, were from Upstate Biotechnology, Inc. (Lake Placid, NY, USA), and phosphospecific antibodies to STAT3, p44/p42 MAP kinase and Akt (S473) were from Cell Signaling Technology, Inc. (Beverly, MA, USA). Anti-insulin (AB3) antibody was purchased from Oncogen (Cambourne, MA, USA), and anti-phosphotyrosine antibody (PY11230) from BD Transduction Laboratories (Heidelberg, Germany). All other chemicals were from Sigma-Aldrich Co. (St Louis, MO, USA), unless stated otherwise.

\section{Cell culture}

For all experiments, we used SV40T-immortalised brown adipocytes from the FVB strain of mice generated as described elsewhere (Klein et al. 1999). Preadipocytes were grown in Dulbecco's modified Eagle's medium (Life Technologies, Paisley, Strathclyde, UK) supplemented with $4.5 \mathrm{~g} / 1$ glucose, $20 \mathrm{nM}$ insulin, $1 \mathrm{nM}$ T3, 20\% fetal bovine serum (Sigma-Aldrich Co., St Louis, MO, USA) and penicillin/streptomycin (BioWhittaker, Vervier, Belgium) (differentiation medium). When confluence was reached, differentiation was induced by complementing differentiation medium further with $250 \mu \mathrm{M}$ indomethacine, $500 \mu \mathrm{M}$ isobutylmethylxanthine and $2 \mu \mathrm{g} / \mathrm{ml}$ dexamethasone for $24 \mathrm{~h}$. After changing back to differentiation medium, cell culture was continued for 5 more days before cells were starved for $24-48 \mathrm{~h}$ with serum-free medium prior to carrying out the experiments.

\section{Determination of leptin secretion}

From day 5 to day 13 of the differentiating process, culture medium was removed from the cells every $24 \mathrm{~h}$ and replaced with fresh medium. Leptin release into the medium was determined using a mouse leptin radioimmunoassay (Linco Research, Inc., St Louis, MO, USA).

\section{Determination of glucose uptake}

Glucose uptake assays were carried out essentially as described previously (Klein et al. 1999). In brief, cells were starved in serum-free medium for $48 \mathrm{~h}$ and washed in Krebs-Ringer-HEPES (20 mM HEPES, $136 \mathrm{mM}$ $\mathrm{NaCl}, 4.7 \mathrm{mM} \mathrm{KCl}, 1.25 \mathrm{mM} \mathrm{MgSO}_{4}, 1.25 \mathrm{mM} \mathrm{CaCl}_{2}$ ). After preincubation with $100 \mathrm{nM}$ leptin for varying periods of time, cells were incubated with $100 \mathrm{nM}$ insulin for $30 \mathrm{~min} .{ }^{3} \mathrm{H}$-Labelled 2-deoxyglucose $\left({ }^{3} \mathrm{H}-2-D O G\right.$; $500 \mathrm{nCi} / \mathrm{ml}$; NEN Life Science Products, Cologne, Germany) was added for 4 min before cells were washed in ice-cold phosphate-buffered saline and lysed with $0 \cdot 1 \%$ SDS. Activity of ${ }^{3} \mathrm{H}-2-D O G$ was measured using a beta scintillation counter.

\section{Western blotting and immunoprecipitation}

Proteins were isolated using whole-cell lysis buffer containing $2 \mathrm{mM}$ vanadate, $10 \mu \mathrm{g} / \mathrm{ml}$ aprotinin, $10 \mu \mathrm{g} / \mathrm{ml}$ leupeptin and $2 \mathrm{mM}$ phenylmethylsulphonyl fluoride (Fluka Chemie AG, Neu-Ulm, Germany). Protein content of lysates was determined by the method of Bradford (1976) using the dye from Bio-Rad (Hercules, CA, USA). Lysates were submitted to SDS-PAGE and transferred to nitrocellulose membranes (Schleicher and Schuell Inc., Keane, NH, USA). Membranes were blocked overnight with rinsing buffer $(10 \mathrm{mM}$ Tris, $150 \mathrm{mM} \mathrm{NaCl}, 0 \cdot 05 \%$ Tween 20, pH 7.2) containing 3\% bovine serum albumin (BSA) (blocking solution). Membranes were then incubated in blocking solution for $1-2 \mathrm{~h}$ with the antibodies indicated. Protein bands were visualised using the chemiluminescence kit from Roche Molecular Biochemicals (Mannheim, Germany) and enhanced chemiluminescence films (Amersham Pharmacia Biotech, Freiburg, Germany). For immunoprecipitation, lysates were prepared as described above, and respective antibodies immobilised to protein G-sepharose beads (Pierce, Rockford, IL, USA) were added for $4 \mathrm{~h}$. Beads were then washed three times with $10 \mathrm{mM} \mathrm{NaCl}, 25.5 \mathrm{mM} \mathrm{KCl}$, $200 \mathrm{mM}$ HEPES, $0 \cdot 05 \%$ Igepal, 1\% BSA, 8.5\% glycerol and $100 \mu \mathrm{M} \mathrm{Na-vanadate,} \mathrm{before} \mathrm{protein-antibody} \mathrm{com-}$ plexes were dissolved in $5 \times$ Laemmli buffer. Subsequent immunoblotting was carried out as described above.

\section{Insulin receptor kinase activity assay}

After preincubation with $100 \mathrm{nM}$ leptin for varying periods of time, cells were incubated with $100 \mathrm{nM}$ insulin for $5 \mathrm{~min}$ and whole-cell lysates were prepared. Insulin receptor kinase activity was determined as described previously (Klein et al. 1993, Krutzfeldt et al. 2000). In brief, lysates were added to microwell plates coated 


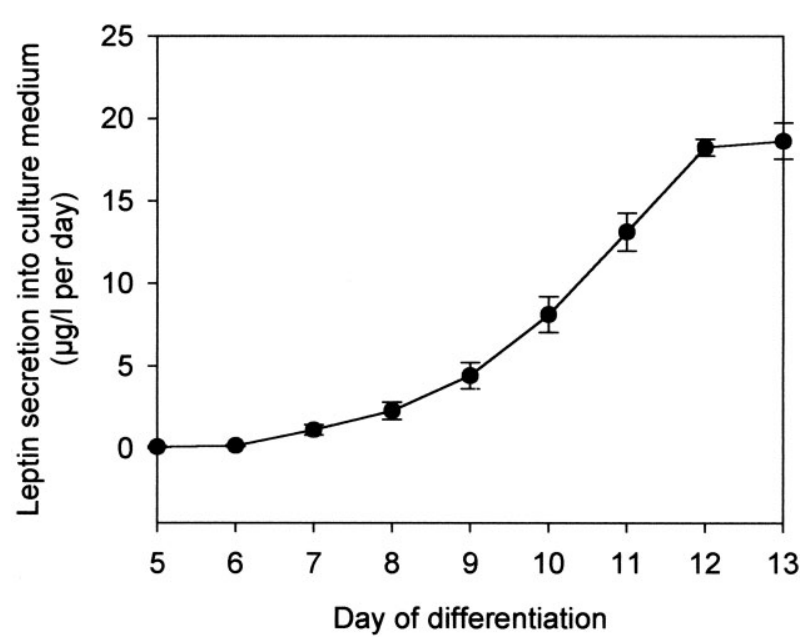

Figure 1 Leptin secretion in brown adipocytes. Culture medium was taken every $24 \mathrm{~h}$ and analysed for leptin content. Results depicted represent the average \pm S.E.M. of six independent experiments.

with anti-insulin receptor antibodies for $24 \mathrm{~h}$ at $4{ }^{\circ} \mathrm{C}$. Incubation of plates with recombinant IRS-1 and $\gamma-{ }^{32} \mathrm{P}-$ ATP (Hartmann $\mathrm{GmbH}$, Braunschweig, Germany) for $2 \mathrm{~h}$ followed, before ${ }^{32} \mathrm{P}$-incorporation into IRS-1 was measured. Insulin binding to the receptor was determined with ${ }^{125}$ I-insulin (Amersham Pharmacia Biotech). Insulin receptor kinase activity is expressed as extent of IRS-1 tyrosine phosphorylation in relation to insulin binding.

\section{Statistical analysis}

Data are presented as means \pm S.E.M. Statistical analyses were performed with Sigma Plot (SPSS Science, Chicago, IL, USA). Statistical significance was determined using the unpaired Student's $t$-test. $P$ values of $<0 \cdot 05$ were considered significant, those of $<0 \cdot 01$ highly significant.

\section{Results}

\section{Differentiation-dependent leptin secretion in brown adipocytes}

In differentiating brown adipocytes, we found a robust increase in leptin release over two orders of magnitude during a 13-day differentiation period (Fig. 1). Leptin levels were first detectable in the culture medium at day 5 at a concentration of $0 \cdot 1 \mu \mathrm{g} / 1$ and exponentially increased from day 7 up to maximal concentrations of about $20 \mu \mathrm{g} / 1$ at day 12 when they reached a plateau (Fig. 1).

\section{Dose- and time-dependent phosphorylation of STAT3 and MAP kinase by leptin}

To confirm leptin signalling in differentiated brown adipocytes, STAT3 and MAP kinase phosphorylation were assessed after leptin treatment. Stimulation with leptin for $5 \mathrm{~min}$ resulted in a significant dose-dependent increase in STAT3 phosphorylation (Fig. 2A). Furthermore, leptin-induced STAT3 phosphorylation was time-dependent with a highly significant maximal increase by about 2-fold after 2 min (Fig. 2B). Also, phosphorylation of p44/p42 MAP kinase was significantly induced approximately $2 \cdot 8$-fold after $5 \mathrm{~min}$ of leptin treatment in a time- and dose-dependent manner (Fig. 2C and D).

\section{Leptin impairs insulin-induced glucose uptake}

Given the direct activation of leptin and insulin-signalling intermediates by leptin, we next investigated potential metabolic effects of leptin crosstalk with insulin. Glucose uptake is a classical biological endpoint of insulin signalling in adipose tissue. Treatment with $100 \mathrm{nM}$ insulin for 30 min induced an approximately 4-fold increase in glucose uptake in differentiated brown adipocytes (Fig. 3A). Leptin treatment alone did not affect basal glucose uptake. However, leptin treatment at a concentration of $100 \mathrm{nM}$ prior to incubation with insulin impaired the insulininduced effect (Fig. 3A). This inhibitory effect was timedependent and first detectable after $15 \mathrm{~min}$ of leptin prestimulation. A highly significant maximum inhibition by approximately $25 \%$ was observed after 60 min (Fig. $3 \mathrm{~A})$. A significant reduction in insulin-induced glucose uptake was also found after $2 \mathrm{~h}$ of leptin pretreatment, but prolonged periods of leptin exposure for up to $24 \mathrm{~h}$ did not show any significant alterations (data not shown).

\section{Leptin acutely reduces insulin receptor kinase activity}

Insulin treatment with $100 \mathrm{nM}$ for $5 \mathrm{~min}$ strongly increased receptor kinase activity (Fig. 3B). Consistent with the inhibitory leptin effect on insulin-induced glucose uptake, prestimulation of cells with $100 \mathrm{nM}$ leptin for 5 min significantly decreased insulin receptor kinase activity by $33 \%$ (Fig. 3B). Leptin-mediated inhibition of receptor kinase activity decreased somewhat after longer pretreatment periods but was still detectable after $60 \mathrm{~min}$ of leptin preincubation (Fig. 3B).

Leptin inhibits insulin-induced IRS-1 tyrosine phosphorylation and binding to phosphatidylinositol 3-kinase but not activation of $A k t$

IRS-1 is a main proximal insulin-signalling intermediate that is tyrosine phosphorylated by the activated insulin receptor kinase and subsequently enables binding and activation of phosphatidylinositol 3-kinase (PI 3-kinase) which, in turn, is pivotal in mediating insulin's metabolic effects (Kahn 1994, Cheatham \& Kahn 1995). IRS-1 tyrosine phosphorylation was strongly induced by insulin stimulation for $5 \mathrm{~min}$ (Fig. 4A). However, similar to 

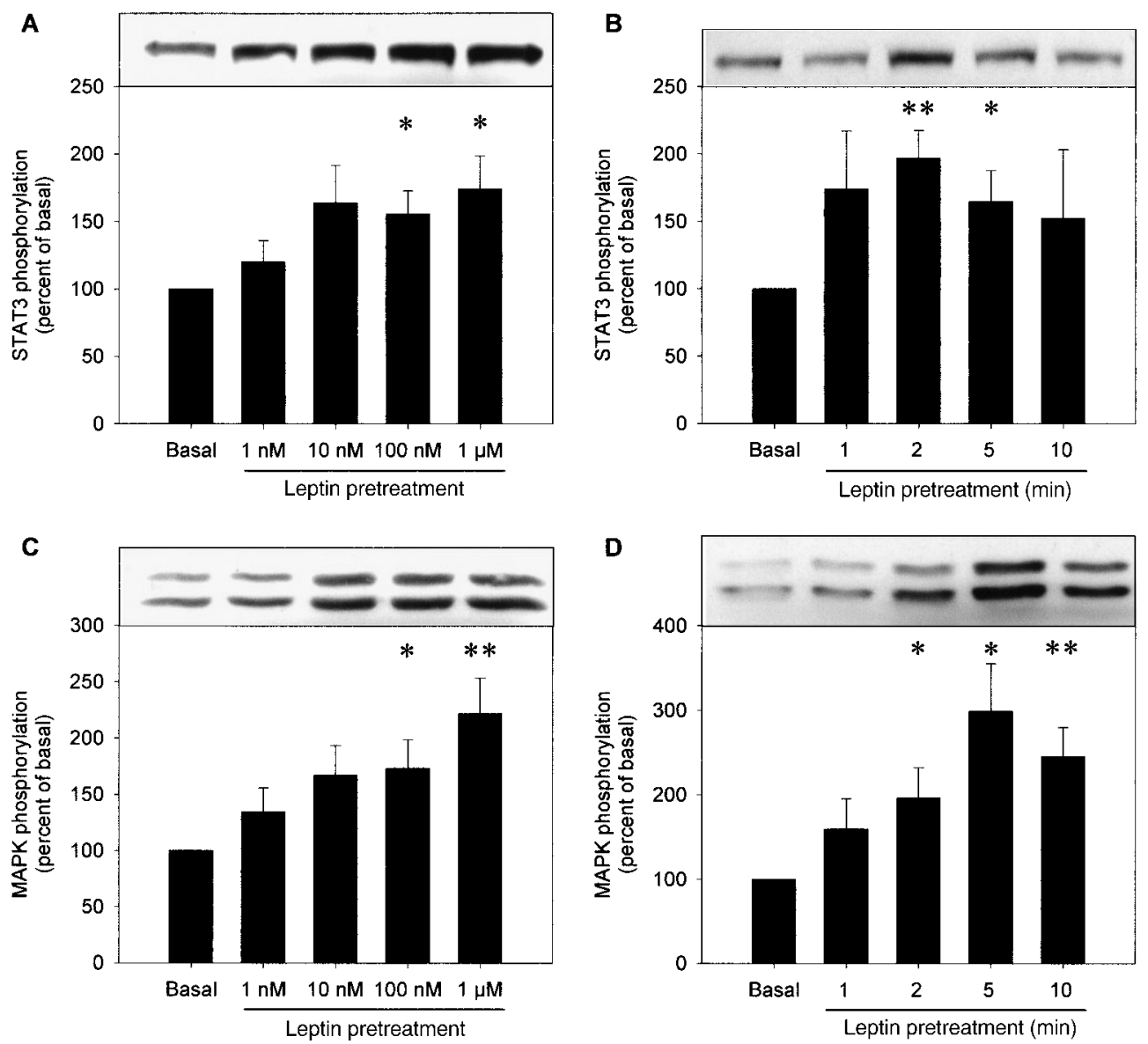

Figure 2 Leptin induces STAT3 and MAP kinase (MAPK) phosphorylation. (A and B) Cells were starved in serum-free medium for $48 \mathrm{~h}$. Subsequently, cells were treated with leptin at the concentrations indicated for $5 \mathrm{~min}$ or for the indicated periods of time $(1 \mu \mathrm{M}$ leptin) respectively, and immunoblots of whole-cell lysates were performed using phosphospecific antibodies to STAT3. (C and D) MAP kinase phosphorylation was measured by immunoblots using phophospecific p44/p42 MAP kinase antibodies after 10 min of leptin treatment at the concentrations indicated or for the indicated times at the concentration of $1 \mu \mathrm{M}$ respectively. Bar graph analyses with the S.E.M. of at least three independent experiments and representative immunoblots are shown in each panel. ${ }^{*} P<0.05$ significant and ${ }^{* *} P<0.01$ highly significant differences as compared with basal phosphorylation.

inhibition of insulin receptor kinase, leptin pretreatment $(100 \mathrm{nM})$ significantly reduced insulin-induced IRS-1 tyrosine phosphorylation. Again, the effect was timedependent (Fig. 4A). Yet, by contrast to insulin receptor kinase activity, significant inhibition of IRS-1 tyrosine phosphorylation was somewhat delayed and appeared to be biphasic with a maximal 60\% inhibition after $60 \mathrm{~min}$ of leptin pretreatment.

Insulin induced an approximately 3-fold increase in IRS-1 binding to the regulatory subunit p85 of PI 3-kinase (Fig. 4B). Consistent with the kinetics for IRS-1 tyrosine phosphorylation, binding of IRS-1 to p 85 was diminished by leptin stimulation in a time-dependent biphasic manner with a maximal $50 \%$ reduction occurring after $60 \mathrm{~min}$ of leptin preincubation (Fig. 4B).
Akt is an important signalling element downstream of PI 3-kinase. Data regarding its involvement in mediating glucose uptake are controversial (Kitamura et al. 1998, Summers et al. 2000, Cho et al. 2001, Hernandez et al. 2001). Insulin stimulation for 5 min strongly induced Akt activation as assessed using a phosphospecific Akt antibody (Fig. 4C). Interestingly, this insulin-induced increase was not altered by leptin pretreatment.

\section{Discussion}

This study has demonstrated strong differentiationdependent leptin secretion in brown adipocytes and autocrine negative effects of this adipocytokine on proximal 
A

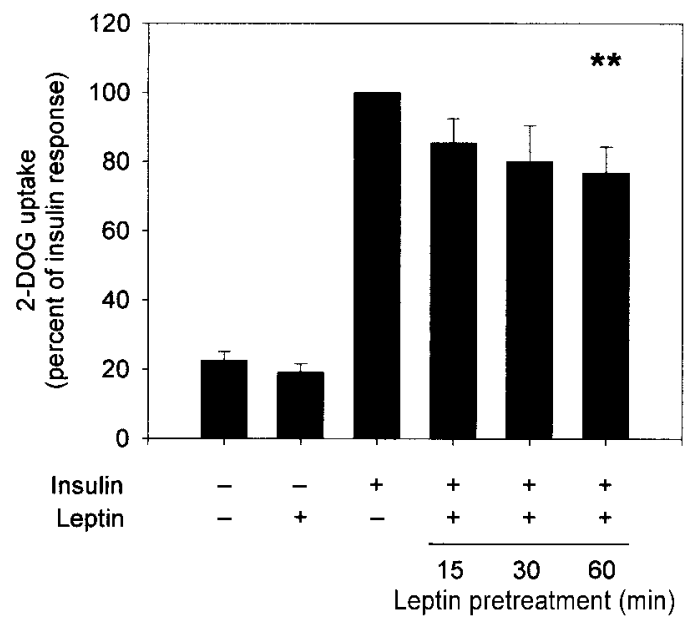

B

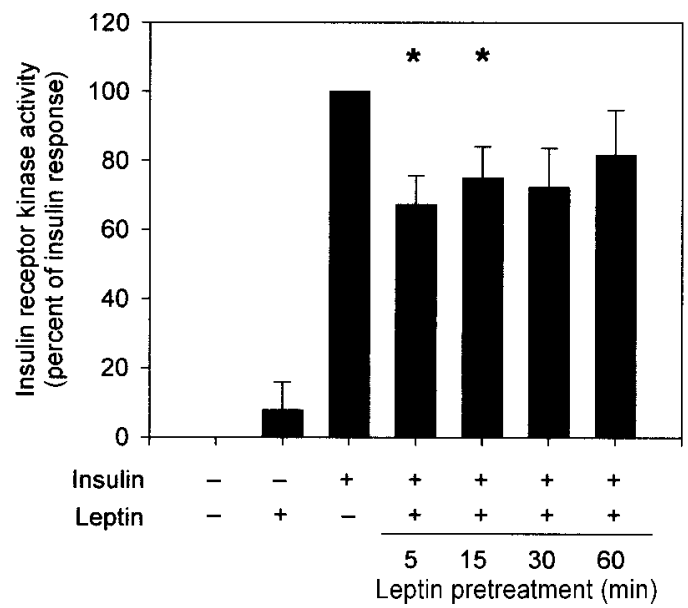

Figure 3 Acute leptin pretreatment inhibits insulin-induced glucose uptake and acutely diminishes insulin-induced insulin receptor kinase activity. (A) Cells were starved in serum-free medium for $48 \mathrm{~h}$ and subsequently exposed to leptin (100 $\mathrm{nM})$ for 15,30 and $60 \mathrm{~min}$ prior to insulin stimulation $(100 \mathrm{nM})$ for $30 \mathrm{~min}$. At the end of the insulin stimulation period, cells were incubated with ${ }^{3} \mathrm{H}$-2-DOG (2-DOG) for $4 \mathrm{~min}$, and uptake was measured in a beta scintillation counter. Bars represent the mean and S.E.M. of ten independent experiments with triplicate determination of each. ${ }^{*} P<0 \cdot 01$ highly significant differences as compared with insulin stimulation alone. (B) Cells were starved in serum-free medium for $24 \mathrm{~h}$ and treated with $100 \mathrm{nM}$ leptin for 5, 15, 30 and $60 \mathrm{~min}$ prior to 5 min stimulation with insulin $(100 \mathrm{nM})$. Insulin receptor kinase activity was determined using ${ }^{32}$ P-labelled IRS- 1 as described in the Methods section. The bar graph analysis represents the mean of three independent experiments with duplicate determination. ${ }^{*} P<0 \cdot 05$ significant differences as compared with the insulin-induced response.

insulin-signalling components resulting in acute and transient induction of insulin resistance.

Studies of leptin expression and secretion in brown adipocytes have been inconsistent. While one study failed to detect leptin (Cinti et al. 1997), others reported either diminished (Moinat et al. 1995) or normal leptin expression and secretion in both human and rodent brown adipocytes (Deng et al. 1997, Zilberfarb et al. 1997, Buyse et al. 2001) as compared with white adipocytes. In the present study, we used a well-characterised adipocyte model of SV40T-immortalised brown fat cells that are similar to primary brown adipocytes in morphological, molecular and functional aspects (Klein et al. 1999, 2000, 2002). We found an increase in leptin release over two orders of magnitude. Thus, our study clearly argues for a robust and differentiation-dependent leptin expression and secretion in brown adipose tissue.

Adipose tissue has emerged as an endocrine organ that is central to the regulation of energy homeostasis and insulin resistance (Ahima \& Flier 2000, Kahn \& Flier 2000, Shuldiner et al. 2001, Spiegelman \& Flier 2001). Recent data suggest that selective impairment of insulin signalling in the thermogenic brown adipose tissue by a tissue-specific disruption of the insulin receptor gene induces a diabetic state (Guerra et al. 2001). Interestingly, our study has demonstrated significant acute negative effects of leptin on insulin-induced glucose uptake. To our knowledge, this is the first report on direct leptin interactions with insulin signalling and action in brown adipocytes. In white adipocytes, few and conflicting studies have been published. While some authors did not find any effects of leptin on insulin-stimulated glucose uptake in isolated rat white adipocytes (Mick et al. 1998, Zierath et al. 1998), others suggest a negative leptin influence on insulin-regulated metabolic actions including glucose uptake in both rat and human adipocytes (Muller et al. 1997, Zhang et al. 1999). One possible explanation for the inconsistency of previous studies in white adipocytes may be the small and transient character of changes induced by leptin stimulation. However, in a physiological and pathophysiological context, these alterations could entail important chronic metabolic consequences by inducing long-lasting changes, e.g. in gene expression patterns or secretion of other adipocytokines implicated in energy balance regulation.

Consistent with the impairment of insulin-induced glucose uptake, we have found an inhibition of important proximal insulin-signalling elements by leptin. Insulin receptor kinase activity is maximally inhibited after $5 \mathrm{~min}$ of leptin pretreatment and subsequently returns to normal, whereas kinetics of downstream signalling events and the final metabolic response are delayed. This may represent an example for the above-mentioned phenomenon of acute transient alterations inducing longer-lasting biological consequences. The kinetics of IRS-1 tyrosine phosphorylation and binding to PI 3-kinase appear to be biphasic. Furthermore, in contrast to PI 3-kinase activity, we did not find leptin-mediated alteration of insulinstimulated Akt activation which is in line with recent studies suggesting a dissociation between PI 3-kinase and Akt in mediating glucose uptake (Kitamura et al. 1998, 
A

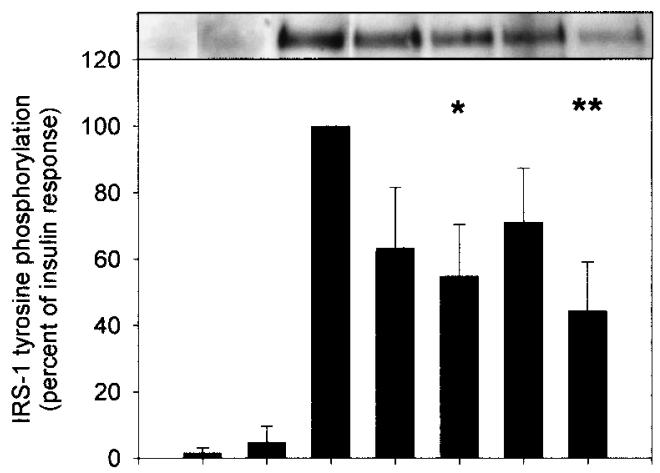

B

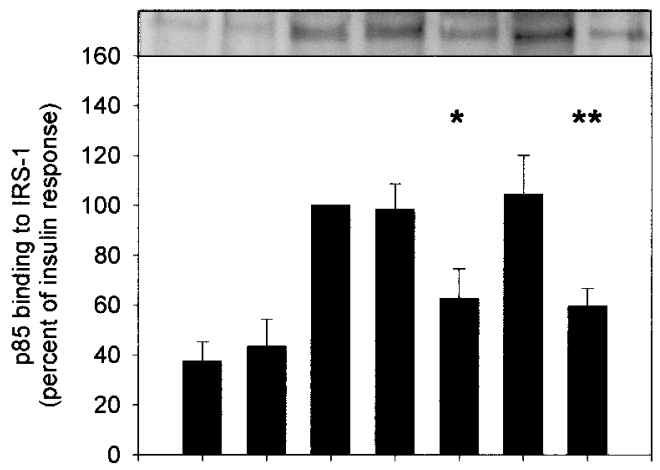

C

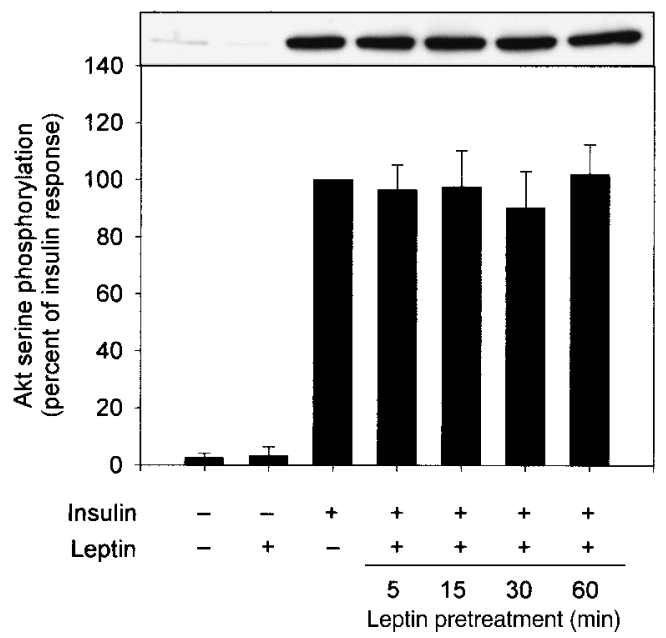

Figure 4 Leptin acutely inhibits proximal insulin-signalling components. Cells were starved in serum-free medium for $24 \mathrm{~h}$ and treated with $100 \mathrm{nM}$ leptin for 5, 15, 30 and 60 min prior to stimulation with insulin ( $100 \mathrm{nM}, 5 \mathrm{~min})$. ${ }^{*} P<0.05$ significant and ${ }^{* *} P<0 \cdot 01$ highly significant differences relative to the insulin response. (A) IRS-1 tyrosine phosphorylation was analysed by immunoprecipitating with an anti-IRS-1 antibody and immunoblotting using an anti-phosphotyrosine antibody. The bar graph analysis represents the mean of five independent experiments (with S.E.M.). (B) p85 binding to IRS-1 was analysed by immunoprecipitating with an anti-IRS-1 antibody and immunoblotting using an anti-phosphotyrosine antibody. Bars represent the mean of four independent experiments (with S.E.M.). (C) Phosphorylation of Akt was analysed by direct immunoblotting using an anti-phosphospecific antibody to Akt (S473). Bar graph analysis represents the mean of four independent experiments (with S.E.M.).
Nadler et al. 2001). Taken together, these findings may reflect additional signalling pathways, which interact on several post-receptor levels. Of note, negative leptin effects on insulin-induced glucose uptake independent of alterations in proximal insulin-signalling components have recently been described in skeletal muscle cells (Sweeney et al. 2001).

In summary, this study has demonstrated differentiation-dependent leptin secretion in brown adipocytes and elucidated autocrine insulin resistanceinducing effects of leptin on major insulin-signalling components. Direct interactions between these two hormonal systems may have important implications for the control of energy balance.

\section{Acknowledgements}

The authors are indebted to M Schümann for help with the leptin radioimmunoassay. This work was supported by grants from the Deutsche Forschungsgemeinschaft (K11131/2-1) and the Deutsche Diabetes Gesellschaft to J K.

\section{References}

Abel ED, Peroni O, Kim JK, Kim YB, Boss O, Hadro E, Minnemann T, Shulman GI \& Kahn BB 2001 Adipose-selective targeting of the GLUT4 gene impairs insulin action in muscle and liver. Nature 409 729-733.

Ahima RS \& Flier JS 2000 Adipose tissue as an endocrine organ. Trends in Endocrinology and Metabolism 11 327-332.

Bradford MM 1976 A rapid and sensitive method for the quantitation of microgram quantities of protein utilizing the principle of protein-dye binding. Analytical Biochemistry 72 248-254.

Buyse M, Viengchareun S, Bado A \& Lombes M 2001 Insulin and glucocorticoids differentially regulate leptin transcription and secretion in brown adipocytes. FASEB Journal 15 1357-1366.

Cheatham B \& Kahn CR 1995 Insulin action and the insulin signaling network. Endocrine Reviews 16 117-142.

Cho H, Mu J, Kim JK, Thorvaldsen JL, Chu Q, Crenshaw EB III, Kaestner KH, Bartolomei MS, Shulman GI \& Birnbaum MJ 2001 Insulin resistance and a diabetes mellitus-like syndrome in mice lacking the protein kinase Akt2 (PKB beta). Science 292 1728-1731.

Cinti S, Frederich RC, Zingaretti MC, De Matteis R, Flier JS \& Lowell BB 1997 Immunohistochemical localization of leptin and uncoupling protein in white and brown adipose tissue. Endocrinology 138 797-804.

Deng C, Moinat M, Curtis L, Nadakal A, Preitner F, Boss O, Assimacopoulos-Jeannet F, Seydoux J \& Giacobino JP 1997 Effects of beta-adrenoceptor subtype stimulation on obese gene messenger ribonucleic acid and on leptin secretion in mouse brown adipocytes differentiated in culture. Endocrinology 138 548-552.

Fasshauer M, Klein J, Ueki K, Kriauciunas KM, Benito M, White MF \& Kahn CR 2000 Essential role of insulin receptor substrate-2 in insulin stimulation of Glut4 translocation and glucose uptake in brown adipocytes. Journal of Biological Chemistry 275 25494-25501.

Fasshauer M, Klein J, Kriauciunas KM, Ueki K, Benito M \& Kahn CR 2001 Essential role of insulin receptor substrate 1 in differentiation of brown adipocytes. Molecular and Cellular Biology 21 319-329. 
Friedman JM \& Halaas JL 1998 Leptin and the regulation of body weight in mammals. Nature $395763-770$.

Guerra C, Navarro P, Valverde AM, Arribas M, Bruning J, Kozak LP, Kahn CR \& Benito M 2001 Brown adipose tissue-specific insulin receptor knockout shows diabetic phenotype without insulin resistance. Journal of Clinical Investigation 108 1205-1213.

Hernandez R, Teruel T \& Lorenzo M 2001 Akt mediates insulin induction of glucose uptake and up-regulation of GLUT4 gene expression in brown adipocytes. FEBS Letters 494 225-231.

Kahn BB \& Flier JS 2000 Obesity and insulin resistance. Journal of Clinical Investigation 106 473-481.

Kahn CR 1994 Banting Lecture. Insulin action, diabetogenes, and the cause of type II diabetes. Diabetes 43 1066-1084.

Kitamura T, Ogawa W, Sakaue H, Hino Y, Kuroda S, Takata M, Matsumoto M, Maeda T, Konishi H, Kikkawa U \& Kasuga M 1998 Requirement for activation of the serine-threonine kinase Akt (protein kinase B) in insulin stimulation of protein synthesis but not of glucose transport. Molecular and Cellular Biology 18 3708-3717.

Klaus S 1997 Functional differentiation of white and brown adipocytes. Bioessays 19 215-223.

Klein HH, Kowalewski B, Drenckhan M, Neugebauer S, Matthaei S \& Kotzke G 1993 A microtiter well assay system to measure insulin activation of insulin receptor kinase in intact human mononuclear cells. Decreased insulin effect in cells from patients with NIDDM. Diabetes 42 883-890.

Klein J, Fasshauer M, Ito M, Lowell BB, Benito M \& Kahn CR 1999 Beta(3)-adrenergic stimulation differentially inhibits insulin signaling and decreases insulin-induced glucose uptake in brown adipocytes. Journal of Biological Chemistry 274 34795-34802.

Klein J, Fasshauer M, Benito M \& Kahn CR 2000 Insulin and the beta3-adrenoceptor differentially regulate uncoupling protein-1 expression. Molecular Endocrinology 14 764-773.

Klein J, Fasshauer M, Klein HH, Benito M \& Kahn CR 2002 Novel adipocyte lines from brown fat: a model system for the study of differentiation, energy metabolism, and insulin action. Bioessays 24 382-388.

Krutzfeldt J, Kausch C, Volk A, Klein HH, Rett K, Haring HU \& Stumvoll M 2000 Insulin signaling and action in cultured skeletal muscle cells from lean healthy humans with high and low insulin sensitivity. Diabetes 49 992-998.

Lowell BB \& Flier JS 1997 Brown adipose tissue, beta 3-adrenergic receptors, and obesity. Annual Review of Medicine 48 307-316.

Mick G, Vanderbloomer T, Fu CL \& McCormick K 1998 Leptin does not affect adipocyte glucose metabolism: studies in fresh and cultured adipocytes. Metabolism: Clinical and Experimental $\mathbf{4 7}$ $1360-1365$
Moinat M, Deng C, Muzzin P, Assimacopoulos-Jeannet F, Seydoux J, Dulloo AG \& Giacobino JP 1995 Modulation of obese gene expression in rat brown and white adipose tissues. FEBS Letters 373 131-134.

Muller G, Ertl J, Gerl M \& Preibisch G 1997 Leptin impairs metabolic actions of insulin in isolated rat adipocytes. Journal of Biological Chemistry 272 10585-10593.

Nadler ST, Stoehr JP, Rabaglia ME, Schueler KL, Birnbaum MJ \& Attie AD 2001 Normal Akt/PKB with reduced PI3K activation in insulin-resistant mice. American Journal of Physiology. Endocrinology and Metabolism 281 E1249-E1254.

Nicholls DG \& Locke RM 1984 Thermogenic mechanisms in brown fat. Physiological Reviews 64 1-64.

Shuldiner AR, Yang R \& Gong D-W 2001 Resistin, obesity, and insulin resistance - the emerging role of the adipocyte as an endocrine organ. New England Journal of Medicine 345 1345-1346.

Siegrist-Kaiser CA, Pauli V, Juge-Aubry CE, Boss O, Pernin A, Chin WW, Cusin I, Rohner-Jeanrenaud F, Burger AG, Zapf J \& Meier CA 1997 Direct effects of leptin on brown and white adipose tissue. Journal of Clinical Investigation 100 2858-2864.

Spiegelman BM \& Flier JS 2001 Obesity and the regulation of energy balance. Cell 104 531-543.

Summers SA, Whiteman EL \& Birnbaum MJ 2000 Insulin signaling in the adipocyte. International Journal of Obesity and Related Metabolic Disorders 24 (Suppl 4) S67-S70.

Sweeney G, Keen J, Somwar R, Konrad D, Garg R \& Klip A 2001 High leptin levels acutely inhibit insulin-stimulated glucose uptake without affecting glucose transporter 4 translocation in 16 rat skeletal muscle cells. Endocrinology 142 4806-4812.

Zhang HH, Kumar S, Barnett AH \& Eggo MC 1999 Intrinsic sitespecific differences in the expression of leptin in human adipocytes and its autocrine effects on glucose uptake. Journal of Clinical Endocrinology and Metabolism 84 2550-2556.

Zierath JR, Frevert EU, Ryder JW, Berggren PO \& Kahn BB 1998 Evidence against a direct effect of leptin on glucose transport in skeletal muscle and adipocytes. Diabetes 47 1-4.

Zilberfarb V, Pietri-Rouxel F, Jockers R, Krief S, Delouis C, Issad T \& Strosberg AD 1997 Human immortalized brown adipocytes express functional beta3-adrenoceptor coupled to lipolysis. Journal of Cell Science 110 801-807.

Received 5 June 2002

Accepted 3 July 2002 